\title{
Clinical evidence based review and recommendations of aerosol generating medical procedures in otolaryngology - head and neck surgery during the COVID- 19 pandemic
}

Andrew Thamboo ${ }^{1 *}$, Jane Lea ${ }^{1}$, Doron D. Sommer ${ }^{2}$, Leigh Sowerby ${ }^{3}$, Arman Abdalkhani ${ }^{1}$, Christopher Diamond ${ }^{1}$, Jennifer Ham ${ }^{4}$, Austin Heffernann ${ }^{4}$, M. Cai Long ${ }^{4}$, Jobanjit Phulka ${ }^{4}$, Yu Qi Wu ${ }^{4}$, Phillip Yeung ${ }^{4}$ and Marc Lammers ${ }^{1}$

\begin{abstract}
Background: Aerosol generating medical procedures (AGMPs) present risks to health care workers (HCW) due to airborne transmission of pathogens. During the COVID-19 pandemic, it is essential for HCWs to recognize which procedures are potentially aerosolizing so that appropriate infection prevention precautions can be taken. The aim of this literature review was to identify potential AGMPs in Otolaryngology - Head and Neck Surgery and provide evidence-based recommendations.

Methods: A literature search was performed on Medline, Embase and Cochrane Review databases up to April 3, 2020. All titles and abstracts of retrieved studies were evaluated and all studies mentioning potential AGMPs were included for formal review. Full text of included studies were assessed by two reviewers and the quality of the studies was evaluated. Ten categories of potential AGMPs were developed and recommendations were provided for each category.

Results: Direct evidence indicates that CO2 laser ablation, the use of high-speed rotating devices, electrocautery and endotracheal suctioning are AGMPs. Indirect evidence indicates that tracheostomy should be considered as potential AGMPs. Nasal endoscopy and nasal packing/epistaxis management can result in droplet transmission, but it is unknown if these procedures also carry the risk of airborne transmission.
\end{abstract}

Conclusions: During the COVID-19 pandemic, special care should be taken when CO2 lasers, electrocautery and high-speed rotating devices are used in potentially infected tissue. Tracheal procedures like tracheostomy and endotracheal suctioning can also result in airborne transmission via small virus containing aerosols.

Keywords: COVID-19, Aerosol, Guideline, Aerosolization, Review

\footnotetext{
*Correspondence: athamboo4@providencehealth.bc.ca

'Division of Otolaryngology Head \& Neck Surgery, Department of Surgery,

University of British Columbia, Vancouver, BC, Canada

Full list of author information is available at the end of the article
}

C C The Author(s). 2020 Open Access This article is licensed under a Creative Commons Attribution 4.0 International License, which permits use, sharing, adaptation, distribution and reproduction in any medium or format, as long as you give appropriate credit to the original author(s) and the source, provide a link to the Creative Commons licence, and indicate if changes were made. The images or other third party material in this article are included in the article's Creative Commons licence, unless indicated otherwise in a credit line to the material. If material is not included in the article's Creative Commons licence and your intended use is not permitted by statutory regulation or exceeds the permitted use, you will need to obtain permission directly from the copyright holder. To view a copy of this licence, visit http://creativecommons.org/licenses/by/4.0/ The Creative Commons Public Domain Dedication waiver (http://creativecommons.org/publicdomain/zero/1.0/) applies to the data made available in this article, unless otherwise stated in a credit line to the data. 


\section{Background}

In the era of globalization, infectious disease outbreaks have brought unprecedented challenges to the medical community. Coronavirus disease 2019 (COVID-19), the clinical condition caused by infection with severe acute respiratory syndrome coronavirus 2 (SARS-CoV-2), rapidly became the world's 6th public health emergency of international concern (PHEIC) declared by the World Health Organization since 2009 [1]. The other PHEICs were the swine flu in 2009, polio in 2014, Ebola virus in 2014 and 2018-20, and Zika virus in 2016 [1]. SARS, small pox and wild type poliomyelitis are automatic PHEICs and do not require declaration from the WHO [2].

Although the main environmental route of transmission of SARS-CoV-2 is through droplets and formites/ surfaces, there is a potential risk of virus spread in smaller aerosols during various medical procedures causing airborne transmission [3-6]. "Airborne transmission" refers to transmission of infection via small ( $<5-10 \mathrm{um})$ inspirable aerosols over extensive distances, whereas "droplet transmission" refers to transmission of infection by (larger) aerosols over short distances directly from the infected person to the susceptible person $[7,8]$.

Various procedures performed by Otolaryngologists to assess and/or treat patients may generate aerosols from areas of high viral shedding, such as the nasal and oralpharyngeal cavity $[6,9]$. Such aerosol generating medical procedures (AGMPs) can lead to close proximity transmission of aerosols, but also in the spread of small aerosols over extensive distances resulting in airborne transmission. According to colleagues in other countries such as China, Italy, and Iran, Otolaryngologists are among the highest risk group of contracting viruses while performing upper airway procedures without appropriate Personal Protective Equipment (PPE) [10]. As there is worldwide limited availability of PPE, it is essential to distinguish which procedures justify the use of high level, airborne precautions. The objective of this literature review is to identify potential AGMPs in Otolaryngology - Head and Neck Surgery (OHNS) and provide evidence-based recommendations.

\section{Methods}

This manuscript followed the published methodology of developing an evidence-based review with recommendations by Rudmik et al. (2011) [11]. A literature search was performed on Medline, Embase and Cochrane Review Databases from inception to April 3, 2020. Given aerosol and droplet terminology has been used interchangeably in the literature, the search included both terms. A screening literature search was first performed using the search term (aerosol* or droplet*) and (procedure or treatment or surgery). The authors, J.H., A.H., C.L., J. P, YWQ, and P.Y. reviewed the articles for topics that pertained to the realm of the head and neck region. All abstracts were reviewed and the following inclusion criteria was applied: English articles, clinical or experimental studies involving procedures in the head and neck region. Studies were excluded if they were opinion papers, review papers, or if only the abstract was published (no manuscript available). This first review of papers led to the following procedures being identified: nasal endoscopy, nasal packing and treatment of epistaxis, endoscopic sinonasal and anterior skull base surgery, CO2 laser ablation, electrocautery, tracheotomy, endotracheal suctioning, oropharyngeal surgery, head and neck reconstruction surgery, dental procedures, mastoid surgery and nebulizer/atomizer. A second focused literature search was performed for each of the aforementioned procedures using the search term (aero-

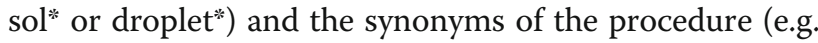
(aerosol or droplet) and (mastoidectomy or mastoid* or mastoid surgery)). The same inclusion and exclusion criteria were applied except this time procedures that were in the head and neck region but not performed by an Otolaryngologist were removed (example: irrigation wash in dental procedure). This was done in order to ensure no further articles were missed on the first search and to keep articles chosen were relevant to the audience of interest. Review papers were also cross referenced to ensure all studies were identified.

The included articles were categorized into various potential AGMP procedures. In this review an AGMP is defined as a medical procedure which has the potential to generate small $(<5-10 \mathrm{um})$ aerosols that can travel greater than $2 \mathrm{~m}$, and therefore an AGMP confers the potential for airborne transmission. In contrast, we defined droplet transmission as involving (larger) aerosols over short distances $(<2 \mathrm{~m})$ directly from the infected person to the susceptible person via mechanisms such as coughing and sneezing. Each AGMP procedure category was assigned to a practicing Otolaryngologist Head \& Neck Surgeon to review the evidence found in the articles, grade the evidence of the articles and develop recommendations for practice. The recommendations were created based on study design, the quality of research, directness of evidence and finally the balance between the potential harm of the procedure and the quality of evidence [12]. Since the potential harm of aerosolizing viable pathogens can have a large impact on the safety of HCWs, a strong recommendation can still be warranted despite low or very low confidence in effect estimates [12]. Direct and high quality evidence was defined as studies evaluating directly, or indirectly particles/aerosol concentrations in air samples. Indirect evidence could be obtained from experimental cadaver models, or retrospective epidemiological data. The manuscript then underwent an iterative review process in the following order: M. L, C.D., J.L., D.D.S., L. S and A.T. 


\section{Results}

The first literature search retrieved 44,110 articles (titles and abstracts), which were screened for potential eligibility. From this, 111 papers fit the inclusion/exclusion criteria, categorized into similar procedures and the second focused search was performed leading to 10 categorical procedures for review (oropharyngeal surgery, head and neck reconstruction surgery, dental procedures summarized under one heading for simplicity) (Fig. 1). The procedures and their evidence were then summarized below.

\section{Nasal Endoscopy}

Only one study evaluating the aerosolization risk during nasal endoscopy was identified (Table 1). Workman et al. (2020) simulated potential aerosolization events using a cadaver with the nasal mucosa coated with fluorescein over a range of endoscopic procedures [13]. The potential aerosolization risk was quantified using a cadaveric model with fluorescein, a blue-light filter and digital image processing. The paper concludes nasal endoscopy did not generate aerosols; however, simulated coughing and sneezing using an atomization device did [13]. The tip of the atomizer was placed posterior to the internal valve, which may not accurately represent a true cough or sneeze. Nevertheless, activation of the atomizer device resulted in particle contamination up to $66 \mathrm{~cm}$ from the nare (produced droplet size: >30um), which by definition is droplet contamination. Both an intact surgical mask and a modified mask with a glove window were successful in eliminating all detectable spread of the particles [13].

Aggregated Evidence: Grade D: one experimental study.

\section{Recommendation:}

Nasal endoscopy can cause coughing and sneezing of the patient, which may result in droplet transmission. It is unknown if this procedure can also lead to airborne transmission of small aerosols over extensive distances. Nasal endoscopy should be considered as a droplet forming procedure and as a potential AGMP.

Strength of recommendation: low.

\section{Nasal Packing and Treatment of Epistaxis}

Three studies evaluated the risk of aerosol contamination during the treatment of epistaxis by visually examining blood contamination of the physician's protective equipment [14-16]. All these studies confirmed that the treatment of epistaxis can cause transmission of blood aerosols within close proximity of the patient (Table 2). This is in line with the aerosol spread seen during coughing and sneezing, which generates aerosols in varying magnitudes and may contain pathogens [17, 18]. The above studies demonstrated that aerosol spread was

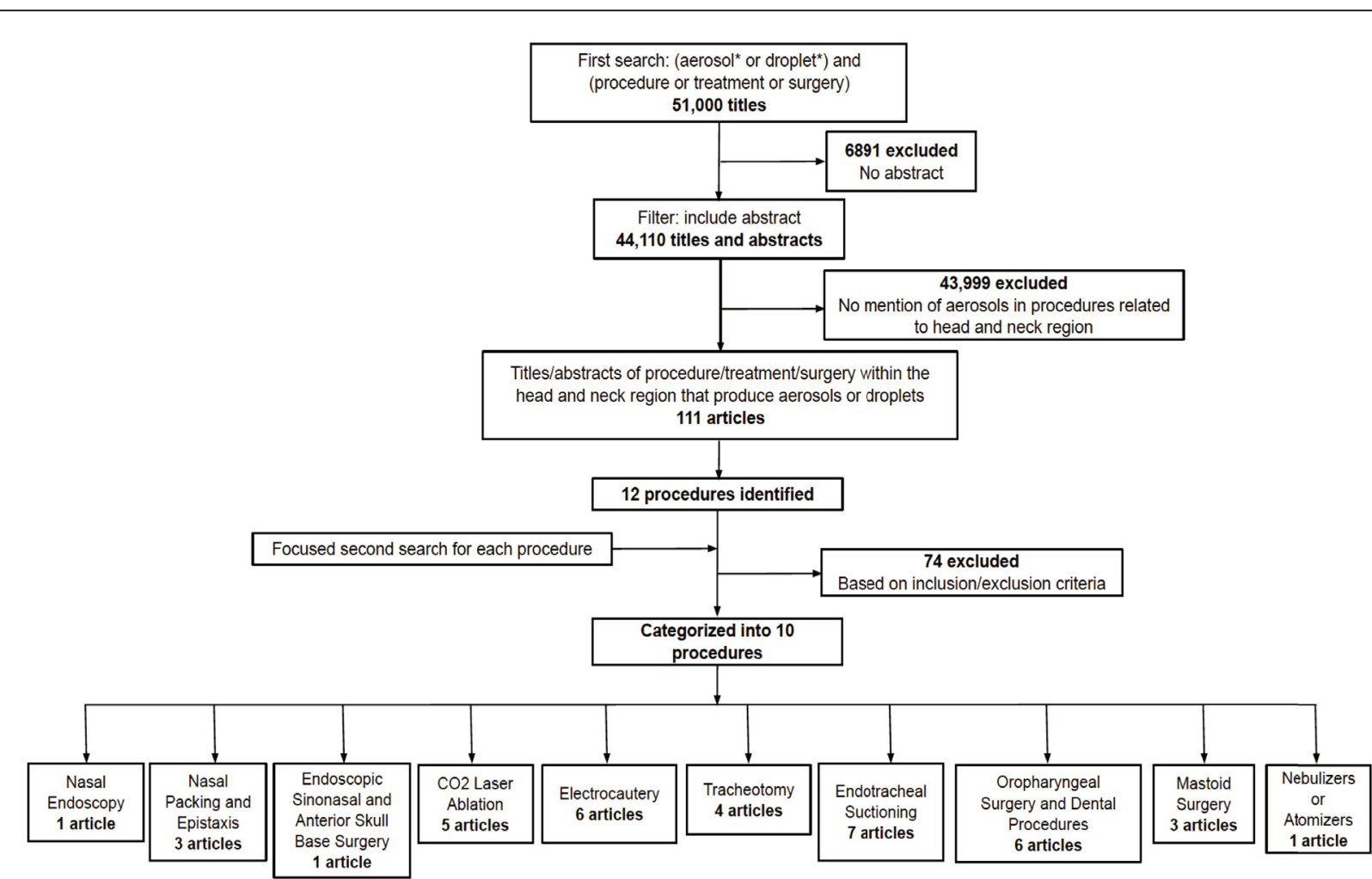

Fig. 1 Evidence Based Review Search Strategy. OHNS = Otolaryngology - Head and Neck Surgery 
Table 1 Characteristics of included studies on nasal endoscopy

\begin{tabular}{|c|c|c|c|c|c|c|c|}
\hline Author, year & Study Design & $\begin{array}{l}\text { Level of } \\
\text { Evidence }\end{array}$ & Subjects (n) & $\begin{array}{l}\text { Study } \\
\text { Groups }\end{array}$ & Study outcomes & Conclusion & $\begin{array}{l}\text { Directness of } \\
\text { evidence }\end{array}$ \\
\hline Workman et al. 2020 [13] & $\begin{array}{l}\text { Experimental } \\
\text { study }\end{array}$ & N/A & N/A & Cadavers & $\begin{array}{l}\text { 1. Visual inspection of } \\
\text { number of fluorescein } \\
\text { droplets generated by } \\
\text { nasal endoscopy, } \\
\text { endonasal surgery with } \\
\text { and without microdebrider } \\
\text { and high-speed drill. } \\
\text { 2. Visual inspection of } \\
\text { number of fluorescein } \\
\text { droplets, generated by } \\
\text { atomizer placed posterior } \\
\text { to the internal valve } \\
\text { (droplet size } 30-100 \text { um) } \\
\text { to simulate cough/sneeze. }\end{array}$ & $\begin{array}{l}\text { 1. Nasal endoscopy and } \\
\text { cold non-powered } \\
\text { endonasal procedures } \\
\text { do not exhibit any } \\
\text { features of AGMPs and } \\
\text { has a lower risk of aerosol } \\
\text { generation. } \\
\text { 2. Droplet spread up to } \\
66 \mathrm{~cm} \text { from the nare, } \\
\text { with peak density around } \\
30 \mathrm{~cm} \text {. (Modified) surgical } \\
\text { masks were able to reduce } \\
\text { the droplet spread. }\end{array}$ & Indirect \\
\hline
\end{tabular}

AGMP aerosol generating medical procedure

significantly reduced if the patient wore a surgical mask during endoscopy or nasal packing $[14,15]$.

Aggregated Evidence: Grade C: one level 3 study, and two indirect, descriptive cross-sectional studies.

Recommendation: There is clinical evidence that treatment of epistaxis can cause coughing and sneezing of the patient, which may result in droplet transmission. It is unknown if these procedures can also lead to airborne transmission of smaller aerosols over extensive distances. Treatment of epistaxis and nasal packing should be considered as droplet forming procedures and as potential AGMPs.

Strength of recommendation: moderate.

\section{Endoscopic Sinonasal and Anterior Skull Base Surgery}

Workman et al. (2020) investigated the aerosolization risk during endoscopic sinonasal procedures (Table 3). In their experimental design, no droplets were observed after performing cold non-powered endonasal procedures or with use of the microdebrider [13]. The authors hypothesized that the low aerosol spread with the microdebrider is due to the relatively low speed of rotation (in comparison to a drill) and the presence of a large-bore suction in the debrider [13]. The study does not explore the possibility of aerosol formation when the microdebrider suction is plugged but still rotating. The use of a high-speed powered drill did create high airflow velocities and was therefore considered aerosol generating and contamination was identified with both endonasal and external activation of the drill. The aerosol size produced from drilling was not stated. Closing or obstructing the nostrils during this procedure did not cease aerosol generation [13].

Aggregated Evidence: Grade D: one experimental study.

\section{Recommendation:}

Based on limited evidence and clinical reasoning, powered instruments, which include the microdebrider and the drill, can result in droplet transmission and airborne transmission, and should be considered as droplet forming procedures and as AGMPs. Cold non-powered procedures are less likely to result in droplet or airborne transmission, as the patient is paralyzed during the

Table 2 Characteristics of included studies on nasal packing and treatment of epistaxis

\begin{tabular}{|c|c|c|c|c|c|c|c|}
\hline Baig et al. 2015 [14] & $\mathrm{RCT}$ with high risk of bias & 3 & 60 & $\begin{array}{l}\text { Adult patients } \\
\text { presenting with } \\
\text { epistaxis. }\end{array}$ & $\begin{array}{l}\text { Number of blood } \\
\text { spatters on surgical } \\
\text { mouth mask and } \\
\text { visor of physician } \\
\text { (visual inspection) }\end{array}$ & $\begin{array}{l}\text { Surgical face masks } \\
\text { worn by patients } \\
\text { covering their mouths } \\
\text { decrease the risk of } \\
\text { blood contamination. }\end{array}$ & Indirect \\
\hline Hassan et al. 2003 [15] & $\begin{array}{l}\text { Descriptive, cross } \\
\text { sectional study }\end{array}$ & $\mathrm{N} / \mathrm{A}$ & 18 & $\begin{array}{l}\text { Adult patients } \\
\text { presenting with } \\
\text { epistaxis. }\end{array}$ & $\begin{array}{l}\text { Number of blood } \\
\text { spatters on surgical } \\
\text { mouth mask, visor } \\
\text { and gowns of physician } \\
\text { (visual inspection) }\end{array}$ & $\begin{array}{l}\text { Surgical face masks } \\
\text { worn by patients } \\
\text { covering their mouths } \\
\text { decrease the risk of } \\
\text { blood contamination. }\end{array}$ & Indirect \\
\hline Wallace et al. 2002 [16] & $\begin{array}{l}\text { Descriptive, cross } \\
\text { sectional study }\end{array}$ & $\mathrm{N} / \mathrm{A}$ & 50 & $\begin{array}{l}\text { Adult patients } \\
\text { presenting with } \\
\text { epistaxis. }\end{array}$ & $\begin{array}{l}\text { Number of blood } \\
\text { spatters on protective } \\
\text { glasses of physician } \\
\text { (visual inspection) }\end{array}$ & $\begin{array}{l}\text { Contamination of the } \\
\text { protective glasses with } \\
\text { blood occurred in 18\% } \\
\text { of cases. }\end{array}$ & Indirect \\
\hline
\end{tabular}


Table 3 Characteristics of included studies on endoscopic sinonasal and anterior skull base surgery

\begin{tabular}{|c|c|c|c|c|c|c|c|}
\hline Author, year & Study Design & $\begin{array}{l}\text { Level of } \\
\text { Evidence }\end{array}$ & Subjects (n) & $\begin{array}{l}\text { Study } \\
\text { Groups }\end{array}$ & Study outcomes & Conclusion & $\begin{array}{l}\text { Directness of } \\
\text { evidence }\end{array}$ \\
\hline Workman et al. 2020 [13] & $\begin{array}{l}\text { Experimental } \\
\text { study }\end{array}$ & $\mathrm{N} / \mathrm{A}$ & $\mathrm{N} / \mathrm{A}$ & Cadavers & $\begin{array}{l}\text { Visual inspection of } \\
\text { number of fluorescein } \\
\text { droplets generated by } \\
\text { nasal endoscopy, } \\
\text { endonasal surgery with } \\
\text { and without microdebrider } \\
\text { and high-speed drill }\end{array}$ & $\begin{array}{l}\text { High-speed drill can } \\
\text { generate high airflow } \\
\text { velocities and aerosolization. } \\
\text { Nasal endoscopy and } \\
\text { endonasal procedures, } \\
\text { including the use of } \\
\text { microdebrider do not } \\
\text { exhibit any features of } \\
\text { AGMPs and has a lower } \\
\text { risk of aerosol generation }\end{array}$ & Indirect \\
\hline
\end{tabular}

procedure, and should be considered as potential droplet forming procedures, but not as AGMPs.

Strength of recommendation: low.

\section{$\mathrm{CO}_{2}$ Laser Ablation}

Smoke samples have confirmed that laser ablation of tissue can generate aerosols [19]. There is consistent evidence revealing that HPV DNA can be present in the surgical smoke generated by $\mathrm{CO} 2$ lasers for the treatment of (laryngeal) papillomatosis and warts (Table 4) [20-23].

Aggregated Evidence: Grade C: two direct, crosssectional studies, one indirect level 4 study, and two experimental studies.

Recommendations: Consistent, direct evidence indicates that $\mathrm{CO} 2$ laser ablation of infected tissue can result in the spread of small, virus containing, aerosols. It is unclear if these aerosols can spread over longer distances, but given the small particle size generated by laser ablation, it is plausible. Laser ablation (CO2) should be considered as a droplet forming procedure and an AGMP.

Strength of recommendation: strong.

\section{Electrocautery}

Three studies assessed particle concentrations during electrocauterization (Table 5) [24, 26, 27]. One crosssectional study and two experimental studies investigated the potential of virus transmission by surgical smoke produced by electrocautery (Table 5) [22, 25, 28]. Electrocautery generates a high concentration of fine particles with diameters in the range of $10 \mathrm{~nm}$ to $1 \mathrm{um}$ [26]. There appears to be a direct positive relationship between the electrical current used during cauterization and particle concentration [24]. Higher current levels resulted in a significant increase in particle aerosolization. Ishihama et al. (2010) demonstrated the presence of aerosolized blood in the air vent filters of operating rooms after oropharyngeal, soft tissue cancer or reconstructive surgeries [27]. In 16 of 21 surgeries (76\%) with identified aerosolized blood in the air filters, electrocauterization was used [27].
In contrast, Subbarayan et al. (2019) assessed the presence of viral DNA in electrocautery smoke produced during the resection of HPV16 positive oropharyngeal cancers [25]. PCR analysis of intraoperative smoke samples obtained from 6 different cases did not reveal HPV16 DNA [25]. This is in line with an experimental study assessing $\mathrm{HIV}-1$ transmission via electrocautery smoke; the surgical smoke generated by cauterization of HIV-1 containing blood was collected and after 4 weeks of culturing no virus could be detected [28].

Aggregated Evidence: Grade C: four, direct crosssectional studies, two experimental studies.

Recommendations: There is consistent, direct evidence indicating that electrocautery can result in small aerosols with potential spread over longer distances. It is uncertain if this can actually lead to clinically relevant transmission of viable pathogens. Electrocautery in tissue with potential high viral loads, i.e. aerodigestive tract, should be considered as a droplet forming procedure and as an AGMP.

Strength of recommendation: moderate.

\section{Tracheotomy}

No studies performed air sample analyses during tracheotomies. In the 2009 retrospective cohort study by Chen et al. (2009), 6 of $17 \mathrm{HCWs}$ performing tracheostomy developed SARS, conferring an odds ratio of 4.15 (univariate analysis 1.50 to $11.50, p<0.01$ ) [29]. However, in their multivariate analysis, tracheotomy was not a significant prognostic factor for the development of SARS [29]. It is unknown whether these infected HCWs were wearing full aerosol PPE, while performing the tracheotomies [29].

Three case series assessed the risk of SARS-CoV-1 infection during tracheotomies performed [30-32]. A total of 21 SARS-CoV-1 positive patients underwent tracheotomy whereby all HCWs used full aerosol PPE and no transmitted infections to HCWs were documented (Table 6) [30-32]. Tracheotomy, historically, has been considered a high risk aerosolizing procedure. This is in part due to the anesthesia literature 
Table 4 Characteristics of included studies on CO2 laser ablation

\begin{tabular}{|c|c|c|c|c|c|c|c|}
\hline Author, year & Study Design & $\begin{array}{l}\text { Level of } \\
\text { Evidence }\end{array}$ & $\begin{array}{l}\text { Subjects } \\
\text { (n) }\end{array}$ & Study Groups & Study outcomes & Conclusion & $\begin{array}{l}\text { Directness of } \\
\text { evidence }\end{array}$ \\
\hline Genangeli, 2019 [18] & $\begin{array}{l}\text { Experimental } \\
\text { study }\end{array}$ & N/A & N/A & $\begin{array}{l}\text { Different tissues, } \\
\text { non-human }\end{array}$ & $\begin{array}{l}\text { Mass spectrometry } \\
\text { of air sample } \\
\text { obtained using } \\
\text { cO2 laser on } \\
\text { different tissues }\end{array}$ & $\begin{array}{l}\text { CO2 lasers can } \\
\text { generate aerosols } \\
\text { with detectable } \\
\text { molecular profiles } \\
\text { for all tissues tested }\end{array}$ & Direct \\
\hline Kashima, 1991 [20] & $\begin{array}{l}\text { Descriptive, cross } \\
\text { sectional study }\end{array}$ & N/A & 22 & $\begin{array}{l}\text { Patients with recurrent } \\
\text { respiratory laryngeal } \\
\text { papillomatosis }\end{array}$ & $\begin{array}{l}\text { PCR of air samples } \\
\text { for HPV DNA }\end{array}$ & $\begin{array}{l}\text { 1. 17/30 vapor } \\
\text { samples were } \\
\text { positive for HPV. } \\
14 \text { paired tissue } \\
\text { and vapor samples } \\
\text { revealed the same } \\
\text { HPV type. } \\
\text { 2. HPV-DNA in the } \\
\text { vapor can be of } \\
\text { concern to the } \\
\text { operating team. }\end{array}$ & Direct \\
\hline Garden, 1988 [21] & $\begin{array}{l}\text { Descriptive, cross } \\
\text { sectional study }\end{array}$ & N/A & 7 & $\begin{array}{l}\text { Patients with plantar } \\
\text { or mosaic verrucae }\end{array}$ & $\begin{array}{l}\text { Electrophoresis and } \\
\text { visualization of HPV } \\
\text { DNA in air samples }\end{array}$ & $\begin{array}{l}\text { 1. Intact human } \\
\text { papillomavirus DNA } \\
\text { was present in the } \\
\text { vapor for two of the } \\
\text { seven patients. } \\
\text { 2. Viral DNA can be } \\
\text { released during the } \\
\text { laser treatment for } \\
\text { verrucae, even with } \\
\text { clinically relevant laser } \\
\text { parameter settings. }\end{array}$ & Direct \\
\hline Sawchuk, 1989 [22] & $\begin{array}{l}\text { Experimental } \\
\text { study }\end{array}$ & N/A & 8 & Human plantar warts & $\begin{array}{l}\text { Dot-blot analysis } \\
\text { of HPV DNA in air } \\
\text { samples }\end{array}$ & $\begin{array}{l}\text { Five of eight laser- } \\
\text { derived vapors were } \\
\text { positive for HPV DNA. }\end{array}$ & Direct \\
\hline Gloster, 1995 [23] & $\begin{array}{l}\text { Case control } \\
\text { study }\end{array}$ & 4 & $31 / 6124$ & $\begin{array}{l}\mathrm{CO} 2 \text { laser surgeons } \\
\text { and patients with } \\
\text { warts }\end{array}$ & $\begin{array}{l}\text { Incidence of HPV } \\
\text { lesions in CO2 } \\
\text { laser surgeons }\end{array}$ & $\begin{array}{l}\text { The overall incidence } \\
\text { of acquired HPV warts, } \\
\text { was not significantly } \\
\text { different from the } \\
\text { incidence of control } \\
\text { patients. However, } \\
\text { the incidence of } \\
\text { nasopharyngeal warts } \\
\text { was higher in CO2 } \\
\text { laser surgeons (13\%) } \\
\text { compared to the } \\
\text { control population } \\
(0.6 \%) \text {. }\end{array}$ & Indirect \\
\hline
\end{tabular}

$P C R$ polymerase chain reaction

HPV Human papilloma virus

DNA deoxyribonucleic acid

illustrating high air flow within the trachea caused by endotracheal intubation, which may result aerosolization and thus an increased risk of virus transmission [29, 33-35].

Aggregated Evidence: Grade D: one level 3 study, and three level 4 studies with clinical reasoning.

Recommendations: There is only indirect evidence and expert opinion suggesting that tracheotomies are high risk of airborne transmission. Although there is paucity of evidence, tracheotomy should be considered as a droplet forming procedure and as an AGMP.

Strength of recommendation: strong.

\section{Endotracheal suctioning}

Four studies revealed that air samples obtained during open endotracheal suctioning in mechanically ventilated patients result in higher concentrations of particulate matter and pathogens like bacteria, viruses and fungi (Table 7) [36-39]. Three retrospective studies, evaluating risk factors for SARS-CoV-1 transmission while providing patient care to SARS patients did not demonstrate that endotracheal suctioning was a significant risk factor for SARS infection [34, 40, 41]. However, in these series, HCWs were wearing adequate airborne protective equipment while providing patient care $[34,40,41]$. 
Table 5 Characteristics of included studies on electrocautery

\begin{tabular}{|c|c|c|c|c|c|c|c|}
\hline Author, year & Study Design & $\begin{array}{l}\text { Level of } \\
\text { Evidence }\end{array}$ & $\begin{array}{l}\text { Subjects } \\
(\mathrm{n})\end{array}$ & Study Groups & Study outcomes & Conclusion & $\begin{array}{l}\text { Directness } \\
\text { of evidence }\end{array}$ \\
\hline Carr, 2020 [24] & $\begin{array}{l}\text { Descriptive, cross } \\
\text { sectional study }\end{array}$ & $\mathrm{N} / \mathrm{A}$ & 36 & $\begin{array}{l}\text { Pediatric } \\
\text { tonsillectomy } \\
\text { patients }\end{array}$ & $\begin{array}{l}\text { Airborne particle } \\
\text { concentration in air } \\
\text { sample during } \\
\text { tonsillectomy. }\end{array}$ & $\begin{array}{l}\text { Airborne particle } \\
\text { concentration during } \\
\text { tonsillectomy was over } \\
9.5 \text { times higher when } \\
\text { electrocautery was set at } \\
20 \mathrm{~W} \text { compared to } 12 \mathrm{~W}\end{array}$ & Direct \\
\hline Subbarayan, 2019 [25] & $\begin{array}{l}\text { Descriptive, cross } \\
\text { sectional study }\end{array}$ & $\mathrm{N} / \mathrm{A}$ & 6 & $\begin{array}{l}\text { Patients with } \\
\text { resection of } \\
\text { oropharyngeal } \\
\text { cancer }\end{array}$ & $\begin{array}{l}\text { PCR of air samples } \\
\text { for HPV16 DNA }\end{array}$ & $\begin{array}{l}\text { None of the electrocautery } \\
\text { fumes sampled yielded } \\
\text { detectable HPV16 DNA }\end{array}$ & Direct \\
\hline $\begin{array}{l}\text { Brüske-Hohlfeld, } \\
2008[26]\end{array}$ & $\begin{array}{l}\text { Descriptive, cross } \\
\text { sectional study }\end{array}$ & N/A & 6 & $\begin{array}{l}\text { Patients } \\
\text { undergoing } \\
\text { abdominal } \\
\text { surgery }\end{array}$ & $\begin{array}{l}\text { Airborne particle } \\
\text { concentration in air } \\
\text { samples }\end{array}$ & $\begin{array}{l}\text { Electro-cauterization and } \\
\text { argon plasma tissue } \\
\text { coagulation induced the } \\
\text { production of very high } \\
\text { concentrations of particles } \\
\text { in the diameter range of } \\
10 \mathrm{~nm} \text { to } 1 \mu \mathrm{m} \text {. }\end{array}$ & Direct \\
\hline Ishihama, 2010 [27] & $\begin{array}{l}\text { Descriptive, cross } \\
\text { sectional study }\end{array}$ & N/A & 54 & $\begin{array}{l}\text { Patients } \\
\text { undergoing } \\
\text { head and neck } \\
\text { surgeries. }\end{array}$ & $\begin{array}{l}\text { Blood aerosols in OR } \\
\text { air conduction filters }\end{array}$ & $\begin{array}{l}\text { Surgical procedures using } \\
\text { electrocautery can result in } \\
\text { aerosolization of blood. }\end{array}$ & Direct \\
\hline Sawchuk, 1989 [22] & $\begin{array}{l}\text { Experimental } \\
\text { study }\end{array}$ & N/A & 7 & $\begin{array}{l}\text { Human plantar } \\
\text { warts }\end{array}$ & $\begin{array}{l}\text { Dot-blot analysis of HPV } \\
\text { DNA in air samples }\end{array}$ & $\begin{array}{l}\text { Four of seven } \\
\text { electrocoagulation-derived } \\
\text { vapors were positive for } \\
\text { human papillomavirus DNA. }\end{array}$ & Indirect \\
\hline Johnson, 1991 [28] & $\begin{array}{l}\text { Experimental } \\
\text { study }\end{array}$ & $\mathrm{N} / \mathrm{A}$ & $\begin{array}{l}32 \text { cell } \\
\text { cultures }\end{array}$ & $\begin{array}{l}\text { HIV-1 inoculated } \\
\text { blood }\end{array}$ & $\begin{array}{l}\text { Isolation of } \mathrm{P}^{-24} \mathrm{HIV}-1 \\
\text { core antigen in cell } \\
\text { cultures obtained from } \\
\text { exposed to surgical } \\
\text { smoked generated in } \\
\text { the presence of HIV-1 } \\
\text { inoculated blood }\end{array}$ & $\begin{array}{l}\text { No HIV-1 was detected in } \\
\text { cells exposed to surgical } \\
\text { smoke }\end{array}$ & Indirect \\
\hline
\end{tabular}

$P C R$ polymerase chain reaction

HPV Human papilloma virus

DNA deoxyribonucleic acid

HIV Human immunodeficiency virus

Aggregated Evidence: Grade C: two direct crosssectional studies, one level 3 and two level 4 studies and two environmental studies.

Recommendations: There is consistent evidence that endotracheal suctioning can result in the spread of small aerosols containing viable pathogens. Long distance spread of small aerosols remains possible under certain conditions. Endotracheal suctioning should be considered as a droplet forming procedure and as an AGMP (especially if the patient is mechanically ventilated).

Strength of recommendation: strong.

\section{Oropharyngeal Surgery and Dental Procedures}

Three studies showed evidence of aerosol production during dental procedures and oropharyngeal surgeries within close proximity of the patient (within two meters) (Table 8) [27, 42, 45]. All of the studies indicated that the use of drills, saws and high pressure water sprays can increase the risk of aerosol formation [27, 42, 45]. One study by Ishihama et al. (2010) revealed evidence of aerosol transmission in a series of 33 operations [27]. Twenty-one surgeries revealed evidence of aerosol transmission of blood onto air vent filters [27]. In $95 \%$ of these surgeries $(20 / 21)$, electrocautery or high-speed rotating instruments were used. In almost all $(11 / 12)$ of the surgeries with no evidence of aerosolization, no electrocautery or high-speed rotating instruments were used [27]. Two other studies provided indirect evidence showing that the PPE of the HCW is frequently contaminated by blood aerosols (Table 8) [43, 44].

Aggregated Evidence: Grade C: three direct, and two indirect cross-sectional studies, and one experimental study.

Recommendations: Consistent and direct evidence indicates the risk of small aerosol formation when highspeed rotating instruments are used in the oral cavity. One study also suggests that these aerosols can become airborne. The use of electrocautery and high-speed rotating instruments (powered instruments) within the 
Table 6 Characteristics of included studies on tracheotomies

\begin{tabular}{|c|c|c|c|c|c|c|c|}
\hline Author, year & Study Design & $\begin{array}{l}\text { Level of } \\
\text { Evidence }\end{array}$ & Subjects (n) & Study Groups & Study outcomes & Conclusion & $\begin{array}{l}\text { Directness of } \\
\text { evidence }\end{array}$ \\
\hline Chen, 2009 [29] & $\begin{array}{l}\text { Retrospective } \\
\text { cohort study }\end{array}$ & 3 & 758 & $\begin{array}{l}\text { HCWs involved } \\
\text { in care of SARS } \\
\text { patients }\end{array}$ & $\begin{array}{l}\text { Risk factors for SARS } \\
\text { infection in HCWs, } \\
\text { based on survey. }\end{array}$ & $\begin{array}{l}\text { Univariate regression } \\
\text { reveals increased OR } \\
\text { for developing SARS: } \\
4.15 \text { ( } 1.50-11.50) \text {, but } \\
\text { this was not significant } \\
\text { in their multivariate } \\
\text { log regression analysis, } \\
\text { which did not reveal } \\
\text { an increased risk of } \\
\text { performing tracheotomy. }\end{array}$ & Indirect \\
\hline Wei, 2003 [30] & $\begin{array}{l}\text { Cohort study, with } \\
\text { high risk of bias }\end{array}$ & 4 & 3 & $\begin{array}{l}\text { HCWs involved in } \\
\text { SARS patients, } \\
\text { requiring } \\
\text { tracheotomies }\end{array}$ & $\begin{array}{l}\text { SARS infection } \\
\text { in HCWs, } 3 \\
\text { tracheotomies }\end{array}$ & $\begin{array}{l}\text { No medical personnel } \\
\text { became infected after } \\
\text { carrying out the } \\
\text { procedure. }\end{array}$ & Indirect \\
\hline Chee, 2004 [31] & Case control & 4 & $124 \mathrm{HCWs}$ & $\begin{array}{l}\text { HCWs involved in } \\
\text { care of SARS patients }\end{array}$ & $\begin{array}{l}\text { SARS infection in } \\
\text { HCWs. } 41 \text { surgical } \\
\text { procedures, including } \\
15 \text { tracheotomies }\end{array}$ & $\begin{array}{l}\text { No transmission of SARS } \\
\text { was reported within the } \\
\text { operating room }\end{array}$ & Indirect \\
\hline Tien, 2005 [32] & $\begin{array}{l}\text { Cohort study, with } \\
\text { high risk of bias }\end{array}$ & 4 & 3 & $\begin{array}{l}\text { HCWs involved in } \\
\text { care of SARS patients }\end{array}$ & $\begin{array}{l}\text { SARS infection } \\
\text { in HCWs, } 3 \\
\text { tracheotomies }\end{array}$ & $\begin{array}{l}\text { Six months after the } \\
\text { procedure, all staff } \\
\text { involved in the } \\
\text { tracheotomies remained } \\
\text { healthy }\end{array}$ & Indirect \\
\hline
\end{tabular}

HCWs health care workers

SARS severe acute respiratory syndrome

$O R$ odds ratio

oral cavity and pharynx should be considered as droplet forming procedures and as AGMPs.

Strength of recommendation: strong.

\section{Mastoid Surgery}

The aerosolized bone dust and irrigation fluid produced during drilling of the mastoid bone can become a potential risk for transmission of disease. Various viruses, including coronaviruses, have been documented in the middle ear mucosa during active infections [47, 48]. There was significant heterogeneity among the three studies and only one study was deemed clinically relevant and of adequate quality [49]. The three studies were found describing aerosolization of bone dust and contaminated irrigation fluid (Table 9) [49-51].

Aggregated Evidence: Grade D: three experimental studies.

Recommendations: Indirect evidence from studies with varying quality indicate that drilling of the mastoid generates small aerosols. Mastoidectomy should be considered as a droplet forming procedure and an AGMP.

Strength of recommendation: moderate.

\section{Nasal Nebulizer/Atomizers}

One experimental study was identified, which revealed that in 9 of the 15 subjects, bacterial contamination of the tip of Venturi atomizers was demonstrated (Table 10) [52].

Aggregated evidence: Grade D: one experimental study.
Recommendations: One experimental study suggests that the nozzle tips of powered atomizers can get contaminated but no evidence that the action of the atomizer generates aerosols from the patient. The use of atomizers/nebulizers should be considered droplet forming procedures given the risk of coughing and sneezing but not an AGMP.

Strength of recommendation: low.

\section{Discussion}

Surgical procedures using $(\mathrm{CO} 2)$ laser vaporization, electrocautery and/or high-speed powered rotating instruments, like microdebriders, drills and saws, can result in airborne transmission of aerosols and should therefore be considered AGMPs. In addition, endotracheal procedures like endotracheal suctioning and tracheotomies should also be considered AGMPs as high tracheal airflow can result in airborne transmission of small aerosols. Nasal endoscopy, epistaxis management and inoffice sinonasal procedures can induce sneezing and coughing of the patient. Although sneezing and coughing is considered to result in mainly droplet transmission, HCWs should be aware that the resulting clouds also contain small, inspirable aerosols, which can impose a risk, when they are working in close proximity to the patient $[4,7,8]$.

For the protection of HCWs during this COVID-19 pandemic, it is not only essential to recognize which procedures are aerosolizing, but physicians should also 


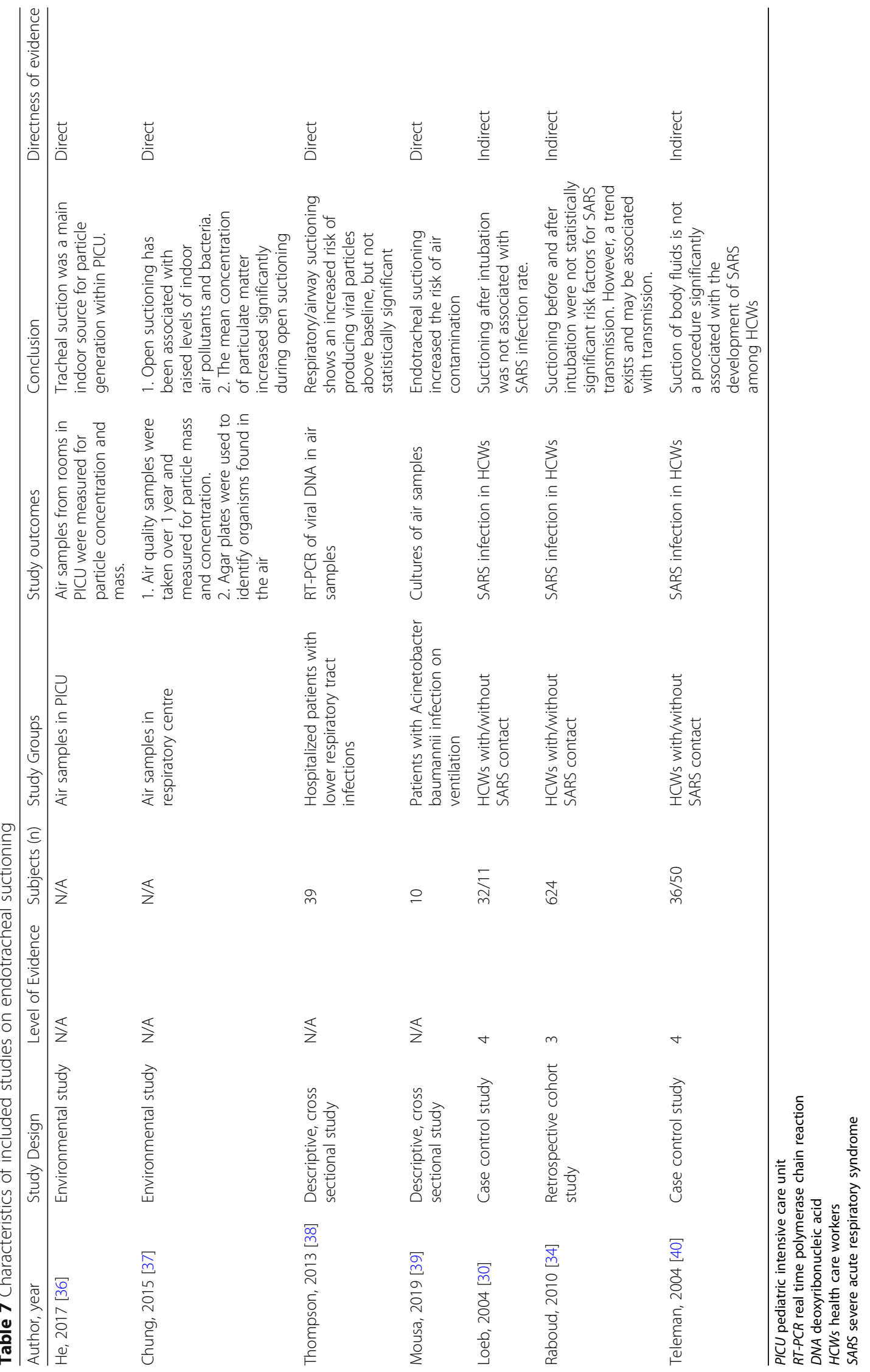




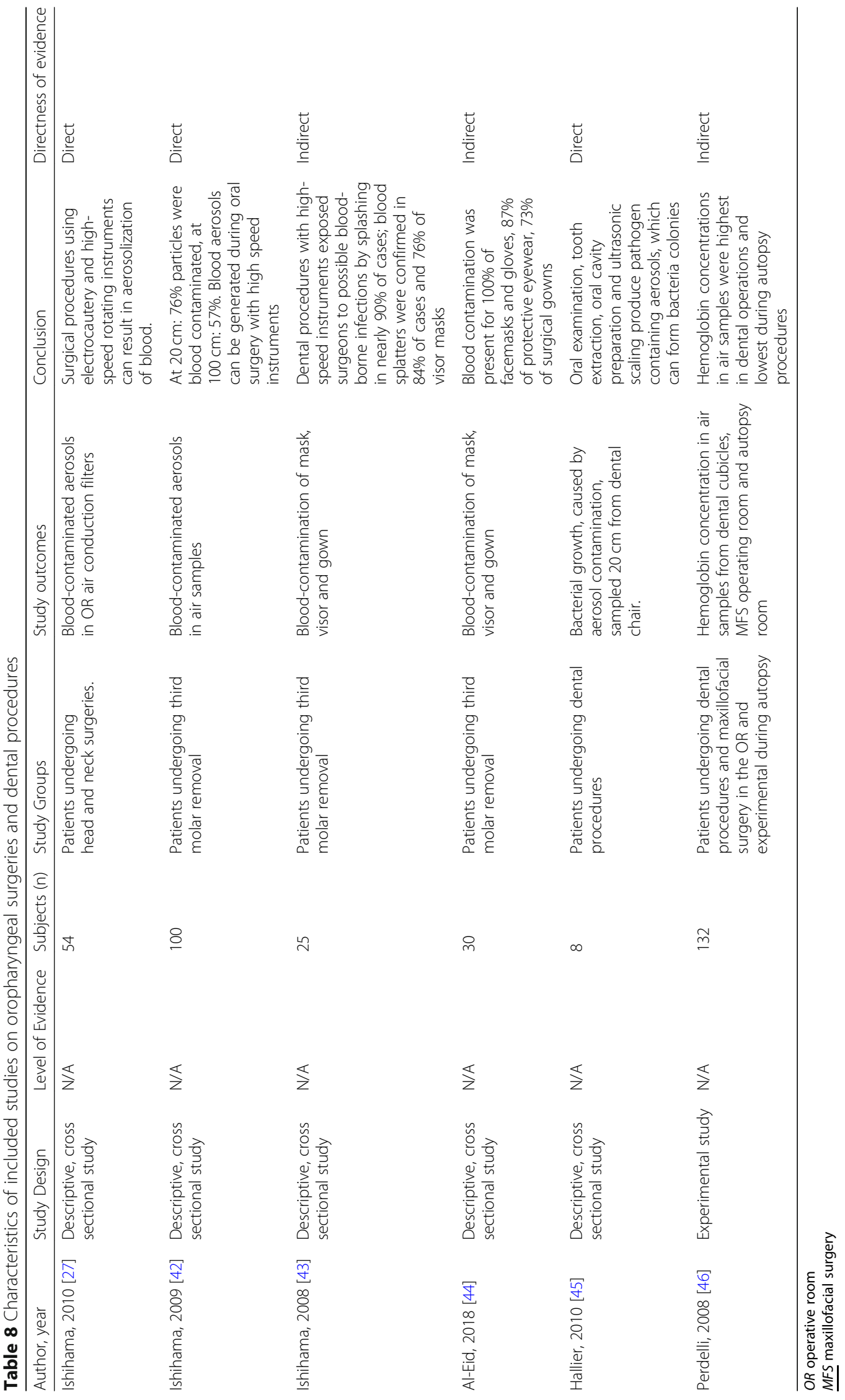




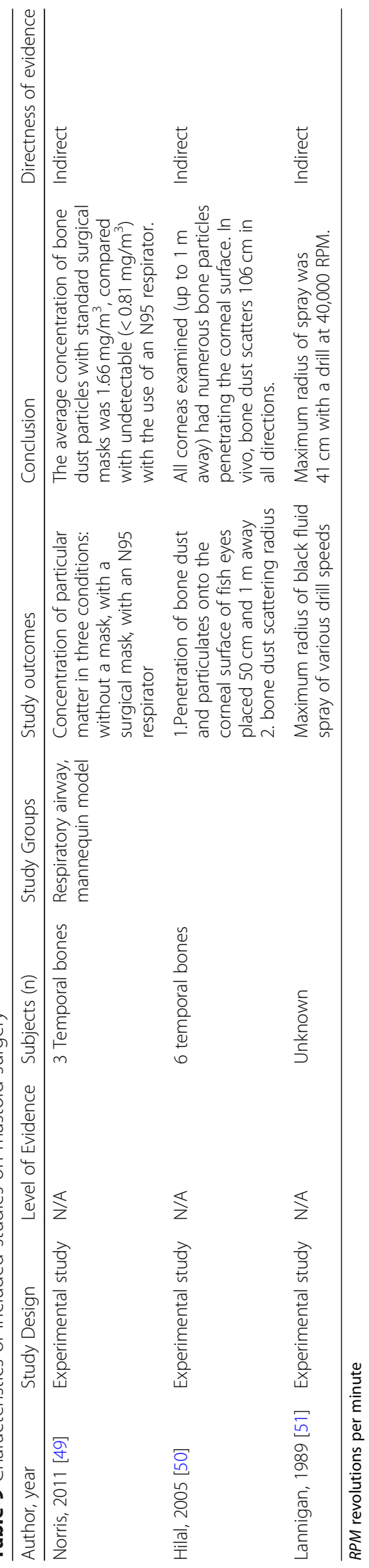


Table $\mathbf{1 0}$ Characteristics of included studies on nebulizers/atomizers

\begin{tabular}{|c|c|c|c|c|c|c|c|}
\hline Author, year & Study Design & $\begin{array}{l}\text { Level of } \\
\text { Evidence }\end{array}$ & Subjects (n) & Study Groups & Study outcomes & Conclusion & $\begin{array}{l}\text { Directness of } \\
\text { evidence }\end{array}$ \\
\hline Tseng, 2014 [52] & $\begin{array}{l}\text { Experimental } \\
\text { study }\end{array}$ & N/A & 15 & Healthy subjects & $\begin{array}{l}\text { Bacterial contamination } \\
\text { of atomizer nozzle tip } \\
\text { (bacterial cultures). }\end{array}$ & $\begin{array}{l}\text { 1. } 18 \text { out of } 30 \text { samples (60\%) } \\
\text { were positive for bacterial } \\
\text { growth at the atomizer tip. } \\
\text { 2. During the spray process, } \\
\text { aerosols were noted traveling } \\
\text { backwards through the } \\
\text { reversed jet flow and attaching } \\
\text { to the nozzle tip, contaminating } \\
\text { the tip. }\end{array}$ & Indirect \\
\hline
\end{tabular}

be aware of the distribution of SARS-CoV-2 throughout the body. The highest viral loads of SARS-CoV-2 have been found in the upper and lower airways, but the virus has also been identified in feces [53]. Viral RNA has even been found in the blood of both symptomatic and asymptomatic COVID-19 patients, and as such, inhaled aerosol of blood may potentially transmit infection [54, 55]. SARS-CoV-2 appears to be quite sensitive to temperature, being largely inactivated at temperatures above $70^{\circ} \mathrm{C}$ [56]. This is important given the high temperature of electrocautery may result in nonviable virus in the plume. This matter is of great importance, not just to our specialty, but to all surgeons operating in this era.

For Otolaryngologists performing aerosol generating procedures, guidelines on PPE use have been suggested in SARS-CoV-2 positive or suspected patients [57, 58]. Although coughing and sneezing mainly results in the emission of larger droplets, the risk of inhaling potentially smaller SARS-CoV-2 infected aerosols should not be neglected, especially if the $\mathrm{HCW}$ is in close proximity. For in-office endonasal procedures and nasopharyngoscopy, in the vast majority of patients, standard level 2 airborne PPE, including N95 masks are recommended. We further recommend keeping as much distance from the patient by using video endoscopy instead of the eyepiece. On the other hand, aerosolizing procedures in SARS-CoV-2 positive or suspected patients warrant extreme airborne precautions and level 3 PPE is recommended by our working group, which include either powered air purifying respirators (PAPR) or body/face/ eye protection with N99/FFP3 respirators (99\% filtration rate, or $95 \%$ if not available) $[57,58]$. In addition, it is recommended that AGMPs are performed in negative pressure rooms to minimize the risk of spread of contaminated aerosols.

One of the major limitations of this review is the fact that most recommendations can only be based on evidence from small, descriptive case-series, experimental studies or indirect retrospective cohort studies. Even if direct evidence was available, the clinical applicability of the various study results can be questioned during the current COVID-19 pandemic. Virus kinetics can differ significantly and this not only includes the potential to survive in aerosols, but also its sensitivity to heat and shear stress during drilling. Extrapolating evidence

Table 11 Summary of included procedures and recommendations

\begin{tabular}{|c|c|c|c|c|}
\hline Procedure & Droplet (Y/N/Potential) & AGMP (Y/N/Potential) & $\begin{array}{l}\text { Aggregated } \\
\text { Evidence }\end{array}$ & $\begin{array}{l}\text { Strength of } \\
\text { Recommendation }\end{array}$ \\
\hline Nasal Endoscopy & Y & Potential & D & Low \\
\hline $\begin{array}{l}\text { Nasal Packing and Treatment } \\
\text { of Epistaxis }\end{array}$ & Y & Potential & C & Moderate \\
\hline $\begin{array}{l}\text { Endoscopic Sinonasal and } \\
\text { Anterior Skull Base Surgery }\end{array}$ & $\begin{array}{l}\text { 1. Powered instruments: } Y \\
\text { 2. Cold non-powered procedures: } Y\end{array}$ & $\begin{array}{l}\text { 1. Powered instruments: } Y \\
\text { 2. Cold non-powered procedures: } N\end{array}$ & D & Low \\
\hline CO2 Laser Ablation & Y & Y & C & Strong \\
\hline Electrocautery & Y & Y & C & Moderate \\
\hline Tracheotomy & Y & Y & $\mathrm{D}$ & Strong \\
\hline Endotracheal Suctioning & Y & Y & C & Strong \\
\hline $\begin{array}{l}\text { Oropharyngeal Surgery and } \\
\text { Dental Procedures }\end{array}$ & Y & Y & C & Strong \\
\hline Mastoid Surgery & Y & Y & $D$ & Moderate \\
\hline Nasal Nebulizer/Atomizers & Y & $\mathrm{N}$ & $\mathrm{D}$ & Low \\
\hline
\end{tabular}

AGMP aerosol generating medical procedure

$Y$ yes

$N$ no 
obtained from studies investigating the potential of airborne transmission and infection of HPV or influenza virus might not hold true for SARS-CoV-2.

Given the limitations of the available research and knowledge surrounding this topic, we recommend HCWs err on the side of caution. As the risks of potential infection with SARS-CoV-2 are significant, a careful balance between the potential harms of the procedure and quality of the available evidence was considered in these recommendations. Therefore, a strong recommendation that a procedure is an AGMP can be provided despite the paucity of high quality and direct evidence. For example, regarding endoscopic use of microdebriders, due to high-speed rotation of the blade, the authors recommend the microdebrider be considered an AGMP as clinical experience intraoperatively conveys frequent microdebrider suction port plugging. To minimize the risk, we suggest the placement of a suction in the nose or suction catheter in the nasopharynx either in the contralateral nostril or via the oropharynx. The use of the suction near the surgical field is also recommended when using electrocautery or the $\mathrm{CO} 2$ laser. Furthermore, given the evidence that endotracheal suctioning is an AGMP, there is a similar theoretical risk of fenestrated suction use in the oral, ear and nasal cavity, for which we suggest the use of level 2 PPE precautions.

These recommendations have been developed by reaching consensus between the authors during the COVID-19 pandemic. A summary of included procedures and recommendations are provided in Table 11. Several gaps in knowledge exist regarding OHNS procedures and the nature of aerosol generation, and further research is needed to provide higher quality evidence based recommendations. As our understanding of COVID-19 evolves and literature grows regarding aerosol generation of various procedures, the above recommendations will need to be revised. Further research is required in the field of OHNS to help our specialty get through this pandemic and better equip us for the next.

\section{Conclusion}

During the COVID-19 pandemic, tracheotomy, endotracheal suctioning, the use of high-speed rotating devices, $\mathrm{CO} 2$ lasers and electrocautery on aerodigestive tissue should be considered AGMPs.

\section{Acknowledgements \\ The authors gratefully acknowledge Dr. Brian Westerberg for his editorial comments.}

\section{Authors' contributions}

All authors reviewed the literature, gathered and analyzed information and data. AT, AA, CD, DS, LS, JL, and ML made major contributions in writing the manuscript. All authors have read and approved the final manuscript.

\section{Funding}

The authors received no specific funding for this work.
Ethics approval and consent to participate

not applicable for this review study.

\section{Consent for publication}

Consent for publication is not applicable for this manuscript.

Data sharing is not applicable to this article as no datasets were generated or analyzed during the current study.

\section{Competing interests}

The authors declare that they have no competing interests.

\section{Author details}

'Division of Otolaryngology Head \& Neck Surgery, Department of Surgery, University of British Columbia, Vancouver, BC, Canada. ${ }^{2}$ Division of Otolaryngology Head \& Neck Surgery, Department of Surgery, McMaster University, Hamilton, ON, Canada. ${ }^{3}$ Department of Otolaryngology, Western University, London, ON, Canada. ${ }^{4}$ Faculty of Medicine, University of British Columbia, Vancouver, Canada.

Received: 15 April 2020 Accepted: 28 April 2020

Published online: 06 May 2020

\section{References}

1. World Health Organization. Statement on the second meeting of the International Health Regulations (2005) Emergency Committee regarding the outbreak of novel coronavirus (2019-nCoV). https://www.who.int/newsroom/detail/30-01-2020-statement-on-the-second-meeting-of-theinternational-health-regulations-(2005)-emergency-committee-regardingthe-outbreak-of-novel-coronavirus-(2019-ncov). Published 2020. Accessed April 16, 2020.

2. Mark A, Hall DO. Mary Anne Bobinski, Nicholas Bagley, I. Glenn Cohen. Health Care Law and Ethics. 9th ed. New York: Wolters Kluwer; 2018.

3. World Health Organization. Advice on the use of masks in the context of COVID-19. Interim guidance 6 April 2020. 2020;WHO/2019-nCov/IPC_Masks/ 2020.3.

4. Bourouiba L. Turbulent gas clouds and respiratory pathogen emissions: potential implications for reducing transmission of COVID-19. JAMA. 2020. [Epub ahead of print].

5. Van Doremalen N, Bushmaker T, Morris DH, et al. Aerosol and surface stability of SARS-CoV-2 as compared with SARS-CoV-1. N Engl J Med. 2020; 382(16):1564-1567.

6. Wang W, Xu Y, Gao R, et al. Detection of SARS-CoV-2 in different types of clinical specimens. JAMA. 2020. [Epub ahead of print].

7. Tellier R, Li Y, Cowling BJ, Tang JW. Recognition of aerosol transmission of infectious agents: a commentary. BMC Infect Dis. 2019;19(1):101.

8. Jones RM, Brosseau LM. Aerosol transmission of infectious disease. J Occup Environ Med. 2015;57(5):501-8.

9. Zou L, Ruan F, Huang M, et al. SARS-CoV-2 viral load in upper respiratory specimens of infected patients. N Engl J Med. 2020;382(12):1177-9.

10. American Academy of Otolaryngology-Head and Neck Surgery. Otolaryngologists and the COVID-19 Pandemic. https://www.entnet.org/ content/otolaryngologists-and-covid-19-pandemic. Published 2020. Accessed April 16, 2020.

11. Rudmik L, Smith TL. Development of an evidence-based review with recommendations using an online iterative process. Int Forum Allergy Rhinol. 2011;1(6):431-7.

12. Schünemann H, Brożek J, Guyatt G, Oxman A. GRADE Handbook. https:// gdt.gradepro.org/app/handbook/handbook.html. Published 2013. Accessed March, 15, 2019

13. Workman AD, Welling DB, Carter BS, et al. Endonasal instrumentation and aerosolization risk in the era of COVID-19: simulation, literature review, and proposed mitigation strategies. Int Forum Allergy Rhinol. 2020. [Epub ahead of print].

14. Baig S, Rashid T, Saleem M. Protection from blood aerosol contamination when managing epistaxis: a study of the effectiveness of a patient mouth mask. Ear Nose Throat J. 2015;94(9):394-8.

15. Hassan MS, Trotter MI. Protection from epistaxis blood aerosol contamination: a novel use of a surgical facemask. Eur Arch Otorhinolaryngol. 2003;260(5):242-3.

16. Wallace $\mathrm{HC}$, Harries PG. Epistaxis and conjunctival contamination--are our ENT trainees at risk? Ann R Coll Surg Engl. 2002;84(5):302-3. 
17. Gralton J, Tovey E, McLaws ML, Rawlinson WD. The role of particle size in aerosolised pathogen transmission: a review. J Inf Secur. 2011;62(1):1-13.

18. Bourouiba L. Images in clinical medicine. A Sneeze. N Engl J Med. 2016; 375(8):e15

19. Genangeli M, Heeren RMA, Porta ST. Tissue classification by rapid evaporative ionization mass spectrometry (REIMS): comparison between a diathermic knife and CO. Anal Bioanal Chem. 2019;411(30):7943-55.

20. Kashima HK, Kessis T, Mounts P, Shah K. Polymerase chain reaction identification of human papillomavirus DNA in CO2 laser plume from recurrent respiratory papillomatosis. Otolaryngol Head Neck Surg. 1991; 104(2):191-5.

21. Garden JM, O'Banion MK, Shelnitz LS, et al. Papillomavirus in the vapor of carbon dioxide laser-treated verrucae. JAMA. 1988;259(8):1199-202.

22. Sawchuk WS, Weber PJ, Lowy DR, Dzubow LM. Infectious papillomavirus in the vapor of warts treated with carbon dioxide laser or electrocoagulation: detection and protection. J Am Acad Dermatol. 1989;21(1):41-9.

23. Gloster HM, Roenigk RK. Risk of acquiring human papillomavirus from the plume produced by the carbon dioxide laser in the treatment of warts. J Am Acad Dermatol. 1995;32(3):436-41.

24. Carr MM, Patel VA, Soo JC, Friend S, Lee EG. Effect of Electrocautery settings on particulate concentrations in surgical plume during tonsillectomy. Otolaryngol Head Neck Surg. 2020. [Epub ahead of print].

25. Subbarayan RS, Shew M, Enders J, Bur AM, Thomas SM. Occupational exposure of oropharyngeal human papillomavirus amongst otolaryngologists. Laryngoscope. 2019. [Epub ahead of print].

26. Brüske-Hohlfeld I, Preissler G, Jauch KW, et al. Surgical smoke and ultrafine particles. J Occup Med Toxicol. 2008;3:31.

27. Ishihama K, Sumioka S, Sakurada K, Kogo M. Floating aerial blood mists in the operating room. J Hazard Mater. 2010;181(1-3):1179-81.

28. Johnson GK, Robinson WS. Human immunodeficiency virus-1 (HIV-1) in the vapors of surgical power instruments. J Med Virol. 1991;33(1):47-50.

29. Chen WQ, Ling WH, Lu CY, et al. Which preventive measures might protect health care workers from SARS? BMC Public Health. 2009;9:81.

30. Wei WI, Tuen HH, Ng RW, Lam LK. Safe tracheostomy for patients with severe acute respiratory syndrome. Laryngoscope. 2003;113(10):1777-9.

31. Chee WW, Khoo ML, Lee SF, Lai YC, Chin NM. Infection control measures for operative procedures in severe acute respiratory syndrome-related patients. Anesthesiology. 2004;100(6):1394-8.

32. Tien HC, Chughtai $T$, Jogeklar A, Cooper AB, Brenneman F. Elective and emergency surgery in patients with severe acute respiratory syndrome (SARS). Can J Surg. 2005;48(1):71-4.

33. Tran K, Cimon K, Severn M, Pessoa-Silva CL, Conly J. Aerosol generating procedures and risk of transmission of acute respiratory infections to healthcare workers: a systematic review. PLoS One. 2012;7(4):e35797.

34. Raboud J, Shigayeva A, McGeer A, et al. Risk factors for SARS transmission from patients requiring intubation: a multicentre investigation in Toronto, Canada. PLoS ONE. 2010;5(5):e10717.

35. Ofner M, Lem M, Sarwal S, Vearncombe M, Simor A. Cluster of severe acute respiratory syndrome cases among protected health care workers-Toronto, April 2003. Can Commun Dis Rep. 2003;29(11):93-7.

36. He C, Mackay IM, Ramsay K, et al. Particle and bioaerosol characteristics in a paediatric intensive care unit. Environ Int. 2017;107:89-99.

37. Chung FF, Lin HL, Liu HE, et al. Aerosol distribution during open suctioning and long-term surveillance of air quality in a respiratory care center within a medical center. Respir Care. 2015;60(1):30-7.

38. Thompson KA, Pappachan JV, Bennett AM, et al. Influenza aerosols in UK hospitals during the H1N1 (2009) pandemic--the risk of aerosol generation during medical procedures. PLoS One. 2013;8(2):e56278.

39. Mousa M, Schwartz D, Carmeli Y, Nutman A. Droplet aerosol dissemination of carbapenem-resistant Acinetobacter baumannii surrounding ventilated patients. Infect Control Hosp Epidemiol. 2019;40(3):365-7.

40. Teleman MD, Boudville IC, Heng BH, Zhu D, Leo YS. Factors associated with transmission of severe acute respiratory syndrome among health-care workers in Singapore. Epidemiol Infect. 2004;132(5):797-803.

41. Loeb M, McGeer A, Henry B, et al. SARS among critical care nurses, Toronto. eEmerg Infect Dis. 2004;10(2):251-5.

42. Ishihama K, Koizumi H, Wada T, et al. Evidence of aerosolised floating blood mist during oral surgery. J Hosp Infect. 2009;71(4):359-64.

43. Ishihama K, lida S, Koizumi H, et al. High incidence of blood exposure due to imperceptible contaminated splatters during oral surgery. J Oral Maxillofac Surg. 2008;66(4):704-10.
44. Al-Eid RA, Ramalingam S, Sundar C, Aldawsari M, Nooh N. Detection of visually imperceptible blood contamination in the Oral surgical clinic using forensic Luminol blood detection agent. J Int Soc Prev Community Dent. 2018;8(4):327-32

45. Hallier C, Williams DW, Potts AJ, Lewis MA. A pilot study of bioaerosol reduction using an air cleaning system during dental procedures. Br Dent J. 2010;209(8):E14

46. Perdelli F1, Spagnolo AM, Cristina ML, et al. Evaluation of contamination by blood aerosols produced during various healthcare procedures. J Hosp Infect. 2008;70(2):174-9.

47. Buzatto GP, Tamashiro E, Proenca-Modena JL, et al. The pathogens profile in children with otitis media with effusion and adenoid hypertrophy. PLoS One. 2017;12(2):e0171049.

48. Alper CM, Winther B, Mandel EM, Hendley JO, Doyle WJ. Rate of concurrent otitis Media in Upper Respiratory Tract Infections with Specific Viruses. Arch Otolaryngol Head Neck Surg. 2009;135(1):17.

49. Norris BK, Goodier AP, Eby TL. Assessment of air quality during mastoidectomy. Otolaryngol Head Neck Surg. 2011;144(3):408-11.

50. Hilal A, Walshe P, Gendy S, Knowles S, Burns H. Mastoidectomy and transcorneal viral transmission. Laryngoscope. 2005;115(10):1873-6.

51. Lannigan FJ, Jones NS, von Schoenberg MV. An avoidable occupational hazard during mastoid surgery. J Laryngol Otol. 1989:103(6):566.

52. Tseng TM, Chen PY, Tseng H, Lin HC, Chang CY, Hung SH. An unexpected route for otolaryngology bacterial contamination with a Venturi atomizer. Rhinology. 2014;52(2):156-61.

53. Cheung KS, Hung IF, Chan PP, et al. Gastrointestinal manifestations of SARSCoV-2 infection and virus load in fecal samples from the Hong Kong cohort and systematic review and meta-analysis. Gastroenterology. 2020. [Epub ahead of print].

54. Chang L, Zhao L, Gong H, Wang L. Severe Acute Respiratory Syndrome Coronavirus 2 RNA Detected in Blood Donations. Emerg Infect Dis. 2020; 26(7). [Epub ahead of print].

55. Huang C, Wang Y, Li X, et al. Clinical features of patients infected with 2019 novel coronavirus in Wuhan, China. Lancet. 2020;395(10223):497-506.

56. Chin AWH, Chu JTS, Perera MRA, et al. Stability of SARS-CoV-2 in different environmental conditions. Lancet Microbe. 2020;S2666-5247(20)30003-3.

57. Givi B, Schiff BA, Chinn SB, et al. Safety recommendations for evaluation and surgery of the head and neck during the COVID-19 pandemic. JAMA Otolaryngol Head Neck Surg. 2020. [Epub ahead of print].

58. Vukkadala N, Qian ZJ, Holsinger FC, Patel ZM, Rosenthal E. COVID-19 and the otolaryngologist - preliminary evidence-based review. Laryngoscope. 2020. [Epub ahead of print].

\section{Publisher's Note}

Springer Nature remains neutral with regard to jurisdictional claims in published maps and institutional affiliations.

Ready to submit your research? Choose BMC and benefit from:

- fast, convenient online submission

- thorough peer review by experienced researchers in your field

- rapid publication on acceptance

- support for research data, including large and complex data types

- gold Open Access which fosters wider collaboration and increased citations

- maximum visibility for your research: over $100 \mathrm{M}$ website views per year

At $\mathrm{BMC}$, research is always in progress.

Learn more biomedcentral.com/submissions 